\section{ASSESSMENT OF SELECTED ON-BOARD BALLAST WATER TREATMENT SYSTEMS IN TERMS OF TECHNICAL AND OPERATIONAL PARAMETERS}

DOI 10.2478/ntpe-2018-0057

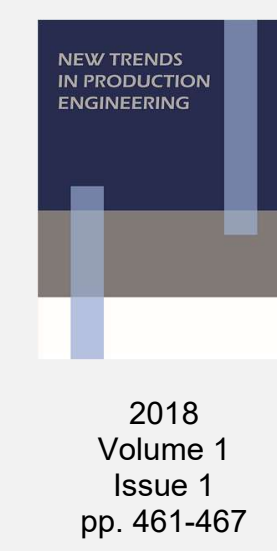

\begin{abstract}
The BWM Convention (Ballast Water Management Convention) will enter into force on 8 September 2017. This document is a response to a very significant problem such as sea water pollution. Due to the Convention, a huge number of companies will be forced to analyze the matter and implement the required provisions. They shall also assess the technologies applied and the fixed systems for ballast water treatment as well as set the requirements in relation to the selection and installation of same at ships. The paper presents the currently applicable regulations and the review of the technologies used for ballast water treatment. There are 5 ballast water treatment systems described herein that are offered by the top producers. The paper includes also the technical and operational parameters of the systems in question. The analysis shall allow for an assessment that may be valuable during the selection process.
\end{abstract}

Keywords: ballast water, environmental protection regulations, treatment technology assessment

\title{
INTRODUCTION
}

To protect the environment, the International Maritime Organisation - IMO has developed and implemented MARPOL 73/78. The main goal of the regulation is to reduce the risk of the environment pollution due to the ships' operation.

During the Earth Summit in Rio de Janerio in 1992 UNCED '92 it was decided that it is essential to draw up and adopt, on a global scale, a convention on water protection against uncontrollable movement of bacteria, viruses and various life forms along with ballast water discharged from ships (Sawicka and Szczepanek, 2013).

The total tonnage of 52 countries that ratified the Convention equals now to $35.144 \%$ of the tonnage of the world fleet.

When making a decision on the ballast water treatment system to be installed, companies should take into consideration its efficiency proven by meeting the BWM Convention requirements and by certificates granted by classification societies. Particular attention should be paid to the systems installed on ships traveling to the North America. They must additionally comply with the requirements regarding the methods and efficiency of water treatment imposed by two USA government bodies namely the US Coast Guard and the US Environmental Protection Agency. Their requirements are much stricter than the one included in the Convention.

The paper describes the risks and threats related with discharging ballast water to ecosystems in terms of the environment. It includes a list of sediments in ballast water the volume of which, according to the BWM Convention, must be established during testing. We have reviewed methods of ballast water treatment and analyzed the solutions and methods of ballast water treatment used in the selected systems of the world leading producers. The methods and equipment for treatment of ballast water from solid contaminants and biological life extermination have been evaluated. The paper includes also a comparison of water treatment efficiency, demand for energy needed by particular systems to operate and the safety of their use for the environment and service. 


\section{BALLAST WATER - THREATS TO THE ENVIRONMENT}

According to the studies of the IMO (American Bureau of Shipping, 2010, CTO S.A., 2007, IMO, 1993), ballast water means water with its suspended matter taken on board a ship to control trim, list, draught, stability or stresses of the ship. It is assessed (American Bureau of Shipping, 2010, IMO, 1993) that every year the world fleet moves from 8 to 10 trillion tons of ballast water around the globe.

In ballast water, one may find harmful aquatic organisms and pathogens. As a result of gravity sedimentation in ballast tanks, sediment is formed containing water organisms and pathogens (Mearns and Reish and Oshida et al. 2017).

Figure 1 presents a scheme of transition of aquatic organisms and pathogens in the ballast water.

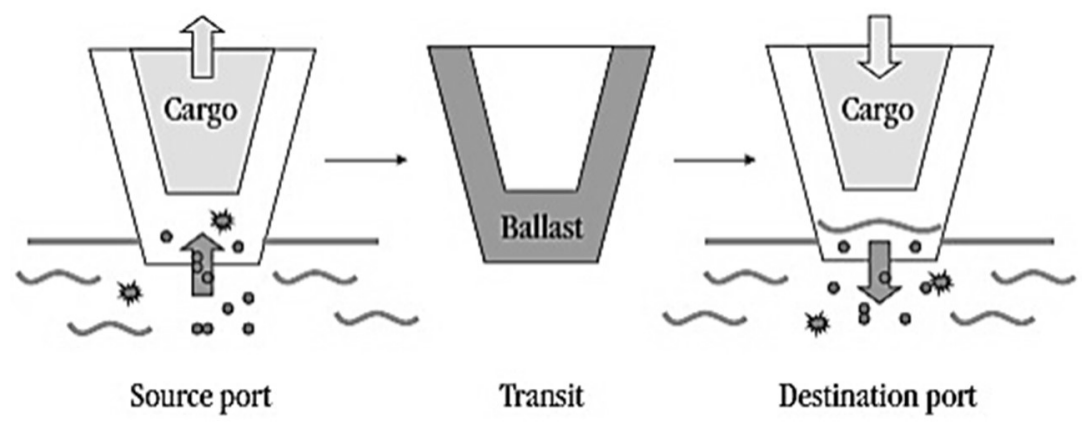

Fig. 1. Scheme of transition of aquatic organisms and pathogens in the ballast water.

Source: Polarcom

The Convention (Report of the Glosten Associates, 2011) defines harmful aquatic organisms and pathogens as aquatic organisms or pathogens which, if introduced into the sea including estuaries, or into fresh water courses, may create hazards to the environment, human health, property or resources, impair biological diversity or interfere with other legitimate uses of such areas.

Numerous tests performed in terms of ballast water composition indicated the following contaminants (Kozłowski, 2009, Leppakoski, 1997, CTO S.A., 2007):

Mechanical contaminants:

- Heavy metal salts including zinc, lead and mercury;

- Nitrates and nitrites;

- Petroleum compounds.

Microbiological contaminants:

- Vibrio cholerae that is a threat to the health and life of people;

- Escherichia coli - this bacterium is a subject of a standard test for drinking water and in swimming areas;

- Intestinal Enterococci, this bacterium is a subject of a standard test for drinking water and in swimming areas;

- Biological contaminants:

- Zooplankton - the most common are the persistent forms, larval stages and adult fish, shrimps and crabs;

- Phytoplankton - microscopic plant-like organisms including algae, cyanobacteria, green algae, diatoms, furrows and others.

Ballast water treatment methods

In order to reduce the threats to the water environment, the MARPOL Convention includes the requirements on the ballast water discharged from ships (Table 1). 
Table 1.

Permissible volume of harmful components in ballast water.

\begin{tabular}{|c|c|}
\hline \multicolumn{2}{|c|}{ Microbiological contaminants } \\
\hline Species & CFU1) \\
\hline Esbrio cholerae & Less than 1 \\
\hline Escherichia coli & Less than 250 \\
\hline \multicolumn{2}{|c|}{ Biological contaminants 1} \\
\hline Organism dimension & Sample content \\
\hline $10 \mu \mathrm{m} \leq \mathrm{a}<50 \mu \mathrm{m}$ & 10 viable organisms $/ \mathrm{cm}^{3}$ of water \\
\hline $\mathrm{a} \geq 50 \mu \mathrm{m}$ & 10 viable organisms $/ 000 \mathrm{dm}^{3}$ of water \\
\hline
\end{tabular}

Source: CTO S.A., 2007

1) CFU - colony forming unit per 100 milliliters of water

In order to attain the required, specified in Table 1, degree of purity of ballast water, efficient methods and technologies of its treatment and neutralization at ships are required.

Mechanical treatment means that biological contaminants are removed. During the treatment process, the particles are separated due to their size and density. For the purpose of filtration, the following are employed (Hydemarine, Zeppelin, Wartsila, Ecochlor, Alfalaval, Sunrui, Nauticexpo, Matuszak 2014).

- Mesh filters - single or multi-layer meshes, mesh size equals from 30 to $50 \mu \mathrm{m}$;

- Microfilters - mesh or fabric filters with mesh diameter of 5-20 $\mu \mathrm{m}$;

- Slotted screens - the height of slots is 30-50 $\mu \mathrm{m}$;

- Hydrocyclones - as per the bench tests they separate $95 \%$ of contaminants from water; the size of particles is greater than $30 \mu \mathrm{m}$ (Nauticexpo)

The treatment method using a hydrocyclone is presented in Figure 2.

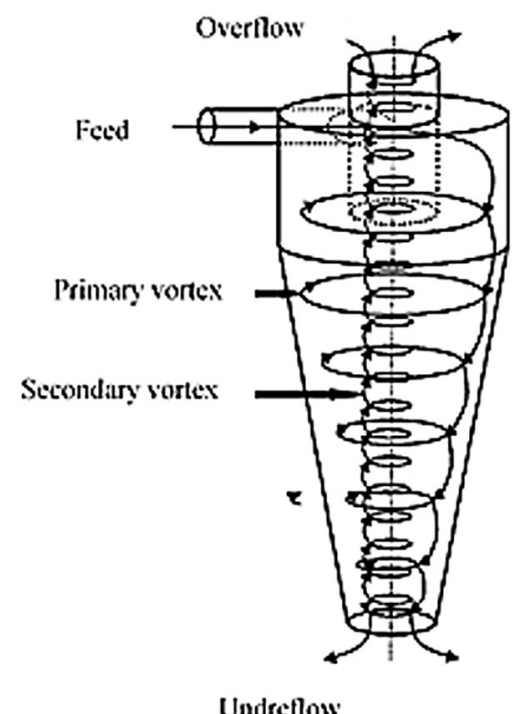

Fig. 2. Schematic diagram of a hydrocyclone (Researchgate).

Physical disinfection is aimed to neutralize microbiological contaminants, rarely biological ones. This method uses (Kozłowski, 2009, Hydemarine Zeppelin, Wartsila, Ecochlor, Alfalaval, Sunrui, Nauticexpo, Impuls, Hielscher):

1. Thermal energy - as research shows, when ballast water is heated to the temperature of $35-45^{\circ} \mathrm{C}$ and when the temperature is maintained for a long period then the biological life of higher organisms is destroyed (e.g. fish, crabs).

2. Ultraviolet (UV) irradiation - Using ultraviolet (UV) irradiation is an effective and environment-friendly method to eliminate the biological life in ballast water. One of the most modern solutions is the Advanced Oxidation Technology. A scheme of the system using the AOT is presented in Figure 3. 
3. Ultrasound disinfection - ultrasound waves are generated in a flowing ballast water stream. Ultrasound disinfection power is related to the occurrence of cavitation phenomena (Mason and Peters, 2002).

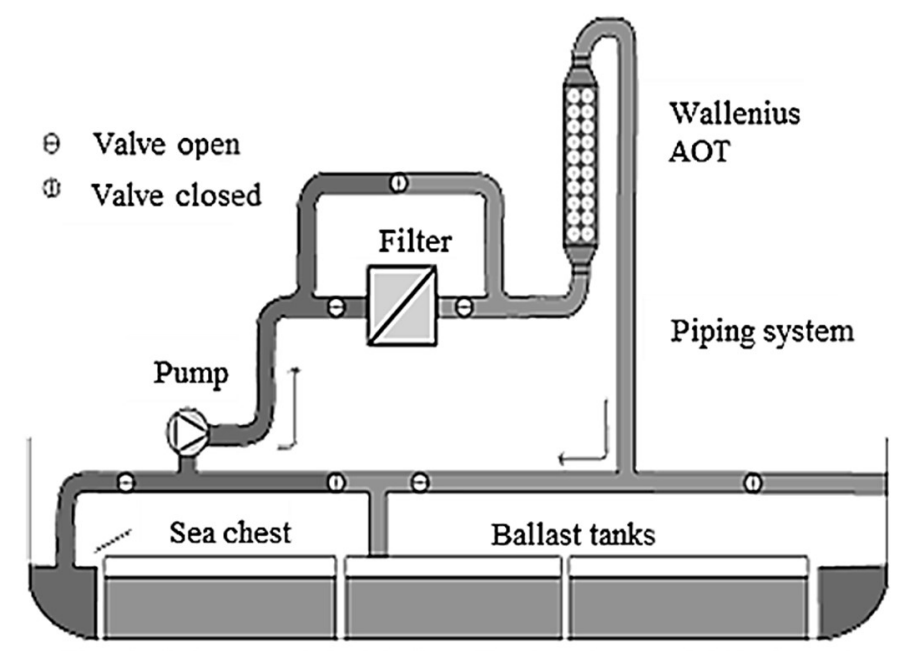

Source: Alfalaval.us

Fig. 3. Advanced Oxidation Technology of Alfa-Laval.

Chemical disinfection is applied to neutralize microbiological and biological contaminants. The following are applied by the method:

1. Ozone gas - when bubbled into the ballast water reacts with contaminants and kills them. After that, it is decomposed.

2. Chlorine chlorine and chlorine dioxide which are classified as oxidizing biocides and do not form metabolic dioxins

3. Electrochemical disinfection - EctoSys, developed by Permascand AG (Hakuyohin), is a system consisting of EctoSys $®$ electrochemical cell (Rwo).

4. Dosing chemicals - neutralization of biological contaminants contained in ballast water takes place by dosing chemicals e.g. PERACLIN Ocean (http://www.greatlakesseaways.com) which a stabilized mixture of peracetic acid, hydrogen peroxide, acetic acid and water.

\section{ASSESSMENT OF SELECTED BALLAST WATER SYSTEMS}

Under the BWM Convention ballast water management means mechanical, physical, chemical, and biological processes, either singularly or in combination, to remove, render harmless, or avoid the uptake or discharge of harmful aquatic organisms and pathogens within ballast water and sediments (CTO S.A., 2007). The processes should be performed during ballasting, deballasting or ballasting and deballasting of ships.

There are two modules which are the most frequently used in the process of ballast water treatment. The first one is the mechanical disinfection module in which, by various physical technics, stable and biological contaminants are being removed. Their size equals more than $50 \mu \mathrm{m}$. The second module is aimed at neutralization of the biological life using mainly physical and chemical methods. A serial connection of the modules ensures that the neutralization process is effective in the second module due to the removal of the large-size contaminants in the first one. Table 2 presents the methods of ballast water treatment applied in the systems provided by the top global producers.

The information allowing for an assessment of the operational parameters of the systems presented in Table 2 is referred to Table 3. 
Table 2.

The methods of ballast water treatment applied in selected systems.

\begin{tabular}{|c|c|c|}
\hline $\begin{array}{c}\text { System/Company } \\
\text { Hyde Guardian } \\
\text { Hyde Marine }\end{array}$ & Mechanical treatment & Biological treatment \\
\hline $\begin{array}{c}\text { BWTS } \\
\text { Unitor }\end{array}$ & Mechanical filter & Ultraviolet (UV) irradiation \\
\hline $\begin{array}{c}\text { SeaCURE } \\
\text { Siemens }\end{array}$ & Mechanical filter & Electrochemical disinfection \\
\hline Ecochlor & Mechanical mesh filter & Chemical disinfection \\
\hline $\begin{array}{c}\text { Pure Balast 3.1 } \\
\text { Alfa - Laval }\end{array}$ & Mechanical mesh filter & AOT- Advanced Oxidation Technology \\
Ultraviolet (UV) irradiation
\end{tabular}

Source: Authors' elaboration. Report of the Glosten Associates, 2011, Leppakoski, 1997,. Hydemarine, Ecochlor, Alfalaval

Table 3.

Operational parameters of selected ballast water treatment systems as per the BWM Convention.

\begin{tabular}{|c|l|c|}
\hline System & \multicolumn{1}{|c|}{ Risks and threats during operation } & Certificate \\
\hline Hyde & None during operation. & IMO \\
\hline Unitor & Need to be careful when replacing UV lamps. & IMO \\
BWTS & $\begin{array}{l}\text { The generated ozone can be hazardous to the } \\
\text { environment. } \\
\text { Threat minimized by the vacuum in the dosing system. }\end{array}$ & \\
\hline Siemens & $\begin{array}{l}\text { Requires chemical replenishment in dispensers. } \\
\text { SeaCURE }\end{array}$ & IMO, US Coast Guard \\
\hline Ecochlor & $\begin{array}{l}\text { Requires chemical replenishment in dispensers. } \\
\text { Obligation to wear personal protective equipment. }\end{array}$ & IMO, US Coast Guard \\
\hline Pure & $\begin{array}{l}\text { None during operation. } \\
\text { Balast 3.1 }\end{array}$ & Need to be careful when replacing UV lamps. \\
\hline
\end{tabular}

Source: Authors' elaboration. Report of the Glosten Associates, 2011, Leppakoski, 1997,. Hydemarine, Ecochlor, Alfalaval

Based on the data included in the documentation provided by the producers, it has been specified and illustrated in Figure 4 what the demand for power required during the operation of each system is.

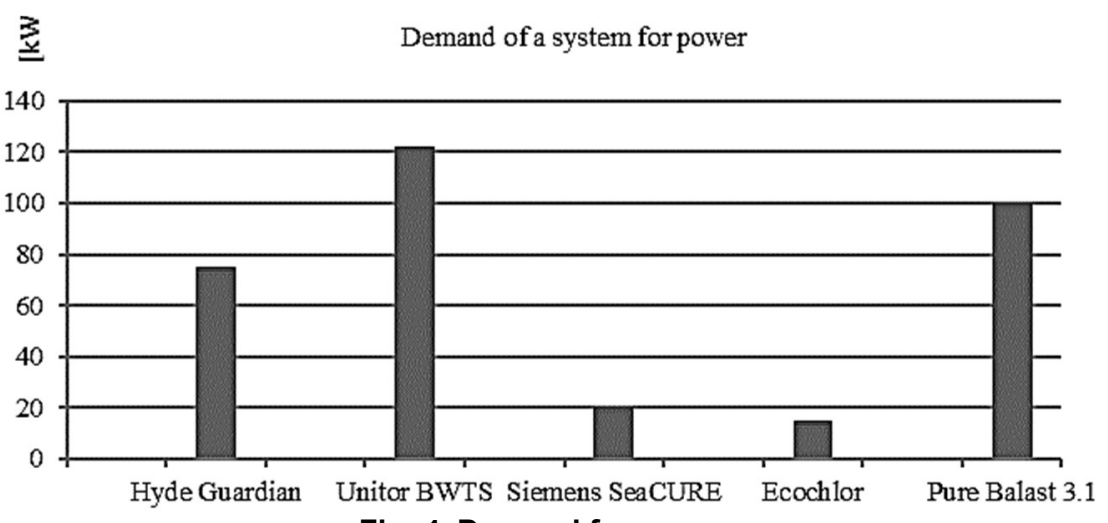

Fig. 4. Demand for power.

Source: Authors' elaboration. Report of the Glosten Associates, 2011, Leppakoski,1997, Hydemarine, Ecochlor, Alfalaval

The demand for power presented in Figure 4 for individual systems has been specified for the mass flow rate of ballast water equaled to $1000 \mathrm{~m}^{3} / \mathrm{h}$.

When analyzing the data in Table 4 it may be noted that the highest energy consumption occurs in the systems equipped with the UV systems. It is related to the maximum power input of each UV lamp. Sequentially, the highest power, equaled to $120 \mathrm{~kW}$, required to operate Unitor BWTS system, is a consequence of the high power of the high-pressure pump pumping ballast water to the cavitation chamber.

The data included in Table 2, 3 and in Figure 4 enabled to assess the selected systems by rating them ( 1 means low rating and 3 means high rating). During the classification process, 
technical and operational parameters have been taken into consideration for a particular system. The assessment results are presented in Table 4.

Table 4.

Selected system assessment.

\begin{tabular}{|l|c|c|c|c|c|}
\hline \multicolumn{1}{|c|}{ System } & $\begin{array}{c}\text { Hyde } \\
\text { Guardian }\end{array}$ & $\begin{array}{c}\text { Unitor } \\
\text { BWTS }\end{array}$ & $\begin{array}{c}\text { Siemens } \\
\text { SeaCURE }\end{array}$ & Ecochlor & $\begin{array}{c}\text { Pure Balast } \\
\mathbf{3 . 1}\end{array}$ \\
\hline Criterion & \multicolumn{5}{|c|}{ Rating } \\
\hline Demanded power & 2 & 1 & 3 & 3 & 2 \\
\hline Threats during operation & 3 & 2 & 1 & 1 & 3 \\
\hline Certificates & 1 & 1 & 2 & 2 & 2 \\
\hline Total rating & $\mathbf{6}$ & $\mathbf{4}$ & $\mathbf{6}$ & $\mathbf{6}$ & $\mathbf{7}$ \\
\hline
\end{tabular}

Source: Authors' elaboration.

The maximum amount of points has been earned by Pure Balast 3.1 due to the highest ratings in particular criterion. That shall mean that the system, according to the paper authors, is the system that is the best tailored to the requirements. Holding the certificates of IMO and the US Coast Guard is extremely important for vessels with unlimited swimming area.

The analysis does not include the purchase price and the cost of installation for the systems as the data is not available.

\section{CONCLUSION}

The matter of threats to the environment due to the transfer of harmful organisms has required to adopt and implement legal regulations, procedures in terms of ballast water. The scale of the problem may be evidenced by the fact that, as shown by the survey, approximately 14 million tons of ballast water are introduced into waters in Polish ports in which even $98 \%$ of zooplankton may survive. The threats should be mitigated since 2017 as the BWM Convention will enter into force.

The most important element in the environment protection systems against the contamination by ballast water one recognizes the systems ensuring effective treatment of the water. Out of a dozen systems developed around the world, only five have been selected and subjected to the analysis. The results showed that the best happened to be Pure Balast 3.1 of Alfa-Laval using UV irradiation. Although its demand for electricity was 4-5 times higher than the remaining systems, the operation of the said system does not create any threats to the environment and operational risks which were significant during the analysis. The more detailed analysis would require gathering data i.a. on system effectiveness (sample tests results of ballast water upon treatment), purchase costs, dimensions, requirements for installation, operation complexity and operational and maintenance costs.

\section{ACKNOWLEDGEMENTS}

This research outcome has been achieved under the research project no. 2/S/IESO/2014 financed from a subsidy of the Polish Ministry of Science and Higher Educations for statutory activities of Maritime University of Szczecin.

\section{REFERENCES}

Alfalaval, Alfalaval Official Website. [online] Available at: www.alfalaval.com/microsites/pureballast/ [Accessed 18 Sep. 2017].

Alfalaval.us, Alfalaval.us Official Website. [online] Available at: www.alfalaval.us/products/ ballast-water-solutions/ [Accessed 26 Sep. 2017].

American Bureau of Shipping, (2010). Ballast Water Treatment Advisory.

CTO S.A., (2007). Określenie zagrożenia introdukcji gatunków obcych w Zatoce Gdańskiej na podstawie badania wód balastowych, rap.tech. $\mathrm{nr}$ RO-07/T-190.

Ecochlor, Ecochlor Official Website. [online] Available at: www.ecochlor.com/system/ [Accessed 15 Sep. 2017].

Hakuyohin, Hakuyohin Official Website. [online] Available at: www.hakuyohin.or.jp/MEPC55_2_4.pdf [Accessed 24 Sep. 2017]. 
Hielscher, Official Website. [online] Available at: www.hielscher.com/pl/ultrasonic-ballast.htm [Accessed 25 Sep. 2017].

Hydemarine, Hydemarine Official Website. [online] Available at: www.hydemarine.com/ballast_water [Accessed 12 Sep. 2017].

IMO, (1993). Wytyczne w sprawie zapobiegania przewożeniu niepożądanych organizmów morskich przez statki w ich wodach balastowych i usuwanych odpadach. Opracowanie 774(18).

Impuls, [online] Available at:.www.impuls.pl/pl/ [Accessed 12 Sep. 2017].

Kozłowski A. (2009). Neutralizacja wód balastowych, Zeszyty Naukowe Akademia Morska w Szczecinie, nr 16 (88), pp.48-58.

Leppakoski E. (1997). Transport of Alien Marine Organisms in Ballast Water Tank - an Ecological Roulette, University of Turku, pp. 89-93;

Mason T.J., and Peters D. (2002). Practical Sonochemistry: Power Ultrasound and Applications, Second Edition, Horwood, Chichester, England.

Matuszak Z. (2014). Streams of energy factors method determining the element validity in the oily water purification system in the vessel gym, Geoconference on water resources, forest, marine and ocean ecosystems, vol II (SGEM 2014) Book Series: International Multidisciplinary Scientific GeoConference-SGEM pp. 693-700

Mearns A.J., and Reish D.J. and Oshida P.S., et al.(2017). Effects of Pollution on Marine Organisms, Water environment research Volume: 89 Issue: 10 pp. 1704-1798.

Nauticexpo, [online] Available at:.www. pdf.nauticexpo.com/pdf/sedna-ballast-brochure/ [Accessed 18 Sep. 2017].

Polarcom, Polarcom Official Website. [online] Available at: www.polarcom.gc.ca/eng/content/meridian-newsletter [Accessed 24 Sep. 2017].

Report of the Glosten Associates, (2011).Ballast Water Treatment System Evaluation for Small Vessels Seattle.

Researchgate, Researchgate Official Website. [online] Available at: www.researchgate.net/ Schematic-diagram [Accessed 26 Sep. 2017].

Rwo, Rwo Official Website. [online] Available at: www.rwo.de/rwo/ressources/files/1/22527RWO.pdf [Accessed 26 Sep. 2017].

Sawicka M., and Szczepanek M. (2013). Legal conditions regarding the energy efficiency of fishing vessels, Scientific Journals of the Maritime University of Szczecin Volume: 36 Issue: 2 pp. 170-174.

Seaways, Seaways Official Website. [online] Available at: www.greatlakesseaways.com/en/pdf/PERACLEAN_Ocean_BWT.pdf [Accessed 26 Sep. 2017].

Sunrui, Sunrui Official - Website. [online] Available at: www.sunrui.net/Products/BalClorTMBallast [Accessed 18 Sep. 2017].

Wartsila, Wartsila Official Website. [online] Available at: www.wartsila.com//wartsila-aquariusec-bwms [Accessed 15 Sep. 2017].

Zeppelin, Zeppelin Official Website. [online] Available at: www.zeppelin.ballastwatertreatment.com [Accessed 15 Sep. 2017]. 